Meta

Journal des traducteurs

Translators' Journal

\title{
Legal Language - Pragmatic Approaches to Its Interconnectivity with Legal Interpretation and Legal Translation
}

\section{Ingrid Simonnaes}

Volume 61, numéro 2, août 2016

URI : https://id.erudit.org/iderudit/1037766ar

DOI : https://doi.org/10.7202/1037766ar

Aller au sommaire du numéro

Éditeur(s)

Les Presses de l’Université de Montréal

ISSN

0026-0452 (imprimé)

1492-1421 (numérique)

Découvrir la revue

Citer cet article

Simonnaes, I. (2016). Legal Language - Pragmatic Approaches to Its Interconnectivity with Legal Interpretation and Legal Translation. Meta, 61(2), 421-438. https://doi.org/10.7202/1037766ar

\section{Résumé de l'article}

Le présent article met d'abord l'accent sur les connaissances théoriques quant aux relations complexes entre la langue juridique, l'interprétation juridique et la traduction juridique. Ces relations sont un véritable défi pour les participants à une situation de communication dans un domaine spécialisé. De notre point de vue, la situation peut être décrite comme un processus cognitif complexe qui adopte une approche pragmatique afin de permettre la compréhension tant des spécialistes (juridiques) que des non-spécialistes.

Ensuite, l'analyse de quelques exemples « typiques " démontre que l'émetteur et le récepteur doivent posséder en commun des connaissances juridiques dans plusieurs sous-domaines afin de parvenir à un acte communicatif réussi. Par conséquent, ces connaissances sont indispensables à de bonnes traductions intra- et interlinguistiques.

Le présent article examine de façon comparative les langues juridiques allemande et norvégienne. La langue juridique constitue la base de l'analyse de la traduction, vue comme une activité où la compréhension/interprétation du texte de départ est d'une importance fondamentale pour le traducteur. Celui-ci doit se méfier des mots (signifiants) et se pencher sur leur sens pour les transposer dans la langue cible.
Ce document est protégé par la loi sur le droit d'auteur. L'utilisation des services d’Érudit (y compris la reproduction) est assujettie à sa politique d'utilisation que vous pouvez consulter en ligne.

https://apropos.erudit.org/fr/usagers/politique-dutilisation/ 


\title{
Legal Language - Pragmatic Approaches to Its Interconnectivity with Legal Interpretation and Legal Translation'
}

\author{
INGRID SIMONNÆS \\ NHH Norwegian School of Economics, Bergen, Norway \\ Ingrid.Simonnas@nhh.no
}

\section{RÉSUMÉ}

Le présent article met d'abord l'accent sur les connaissances théoriques quant aux relations complexes entre la langue juridique, l'interprétation juridique et la traduction juridique. Ces relations sont un véritable défi pour les participants à une situation de communication dans un domaine spécialisé. De notre point de vue, la situation peut être décrite comme un processus cognitif complexe qui adopte une approche pragmatique afin de permettre la compréhension tant des spécialistes (juridiques) que des nonspécialistes.

Ensuite, l'analyse de quelques exemples «typiques» démontre que l'émetteur et le récepteur doivent posséder en commun des connaissances juridiques dans plusieurs sous-domaines afin de parvenir à un acte communicatif réussi. Par conséquent, ces connaissances sont indispensables à de bonnes traductions intra- et interlinguistiques.

Le présent article examine de façon comparative les langues juridiques allemande et norvégienne. La langue juridique constitue la base de l'analyse de la traduction, vue comme une activité où la compréhension/interprétation du texte de départ est d'une importance fondamentale pour le traducteur. Celui-ci doit se méfier des mots (signifiants) et se pencher sur leur sens pour les transposer dans la langue cible.

\section{ABSTRACT}

The purpose of this paper is to enhance existing insights into the complex relationship between legal language, legal interpretation and legal translation that challenges the participants of a particular domain-specific communicative situation. This situation can be described as a complex communicative-cognitive procedure taking into consideration a pragmatic approach to reach its addressees on a continuum from lay persons to experts.

The analysis of some "typical" examples shows (not surprisingly) that different kinds of knowledge are necessary in order to achieve a felicitous communicative act in which a high degree of specialist knowledge is of paramount importance to a successful result both in intra- and interlingual translation.

The particular legal language under scrutiny, in other words German contrastive to Norwegian, form the basis for the analysis of the activity of translation in which the translator must be able to understand/interpret the text and must be aware of not taking the words at their "face value" to be able to render their meaning in the target language.

\section{MOTS-CLÉS/KEYWORDS}

langue juridique, interprétation juridique, traduction juridique, pragmatique legal language, legal interpretation, legal translation, pragmatics 


\section{Introduction}

An increasing interest in the research on Language for Special Purposes (LSP) and specialised discourse is currently demonstrated in a host of publications. Of special interest for the purpose of this paper is the research on legal language as one particular LSP in different interdisciplinary settings, such as the works by Kischel (2009), Goddard (2010), Poscher (2012), Engberg (2012), Bix (2012) and Mattila (2013).

I use legal language, as a particular LSP (Kurzon 1997; Tiersma 1999; Tiersma and Solan 2012) and, from a pragmatic point of view investigate its interconnectivity with legal interpretation as a prerequisite to legal translation. The empirical data are taken from written texts only ${ }^{2}$ with special focus on comprehension and communication in intercultural contexts.

Looking back only a few decades, the main interest in LSP research was foremost in investigating linguistic subsystems ("Fachsprache(n)," Hoffmann 1984). In contrast, current research frequently focuses on specialist communication ("Fachkommunikation," for example, Picht 1996; Baumann 2004) by investigating how specialist knowledge is conveyed while simultaneously taking into account the prevalent role that context plays in such a communicative act. Pragmatics, being the subdomain of linguistics which focuses on the actual usage of words in context, may therefore serve as an adequate basis for this study. Its aim is to enhance existing insights into the complex relationship between legal language, legal interpretation and legal translation by way of a model based on Ogden and Richards's semantic triangle (1923). In their semantic triangle the connection goes between symbol and referent via thought, whereas in my proposed model, the connection is between legal language and legal translation via legal interpretation.

'Legal language' is ambiguous and needs clarification about what it refers to and how it is used in this paper. This is discussed in section 2 with a short review of the state-of-the art studies on legal language and with my working definition of the concept of legal language. The remainder of the paper is divided into a section on legal interpretation (section 3) and subsequently a section on legal translation (section 4). By way of illustration some examples from monolingual and bilingual legal translation are used in section 5 to demonstrate the pragmatic results of the interconnectivity between legal language, legal interpretation and legal translation. Section 6 offers some concluding remarks.

\section{The concept of 'legal language'}

For the purpose of this paper, the main focus is on German legal language or more precisely the legal language in the Federal Republic of Germany and does not take into account other German-speaking countries. In addition, studies on English legal language will to some degree be taken into consideration due to the dominant role of English in the scientific community.

To my knowledge, one of the first definitions in German of 'legal language' is given by Lane (1975: 33) who defined legal [and administrative] terminology (!) as "the language in which laws and other regulations, judicial decisions, treaties and documents of all descriptions and [...] treaties on law [...] are framed."

When Lane (1975) emphasized terminology/technical terms as the most obvious feature of legal language, this was well in line with the then usually held view on 
terminology as the defining feature of LSP (Hoffmann 1976/1985: 21) in general, and in particular of legal language (for example, Müller-Tochtermann 1959).

Pragmatic aspects such as communication situation, social setting, participants' roles and their language use (parole; Saussure 1916/1967) were first taken into consideration after the so-called pragmatic turn. However, Lane was already concerned about the communicative situation saying: "It [the language] is used by jurists and administrators in the daily exercise of their profession" (Lane 1975: 33-34; our emphasis). With respect to the communicators in such settings, a vertical continuum from expert to expert at the one end, to expert to non-expert at the other end (Oksaar 1979; Homberger 1990; Picht 1999 and Heutger 2006) is traditionally acknowledged, and my examples in section 4 can be classified within this continuum.

As indicated in section 1, 'legal language' itself is ambiguous. Some scholars differentiate between legal language and language of the law (for example, Hattenhauer 1987 and Kurzon 1989). Busse (1999) uses 'language of the law' (Gesetzessprache) as the empirical basis for his investigation. Mellinkoff (1963) and Tiersma (2012) also do the same - the latter from a historical point of view - to name but a few studies. According to Mazzarese (2000: 178), 'legal language' can designate either the lawmaker language (the language of law), or the jurist language (the language of legal dogmatics), or the judicial language (the language of adjudication). Sometimes the language of the law is also referred to in the sense of 'legislative language' or 'language of legislation.' Yet other scholars simply use the term 'legal discourse' (for instance, Bhatia, Candlin, et al. 2003, Gotti and Williams 2010). I use 'legal language' in this paper in the sense of 'language of the law' and where necessary use 'legal language in a broad sense' when referring to language use other than in legal norms.

\subsection{Particular features}

Notwithstanding the possible differentiation between legal language, language of the law and language of adjudication, there seems to be consensus about some common features particularly with respect to the language of the law. The most prominent are:

- Vagueness

- Seemingly coincidence with language for general purpose (LGP)

- High degree of abstraction

- Polysemy and synonymy

- Prescriptivity

- Plurality of addressees

- Transdisciplinarity

- Terminology

In what follows, I briefly comment on these features by taking German legal language (use) into account. The Norwegian legal language (use) is given much less attention due to the fact that to the best of my knowledge there is rather scarce literature on this topic. ${ }^{3}$

One reason for this is obviously that Norwegian is a Language of Lesser Diffusion (LLD). 


\subsubsection{Vagueness}

The phenomenom of vagueness is an often discussed feature of legal language (for example, Christie 1964; Gilbertson 1988; Bowers 1989; Endicott 2000, 2001 and 2005; Bhatia, Engberg, et al. 2005; Simonnæs 2007). A common argument is that precision, seen as counterpart to vagueness, in legal language is not always seen as the best way in regulating society, a fact that the lawmakers are well aware of (Endicott 2001: 379). Similarly, Tremblay, for example, argues for the inevitability of vagueness (l'emploi de termes flous est inévitable) in particular with respect to legislative drafting (Tremblay 2006: 127). And Clauss (1974) addresses the "apparent precision" (Scheinpräzision) of legal language by examining different causes for the apparent precision such as for instance ambiguity (Mehrdeutigkeit) which other authors would instead rather qualify as vague.

It has been argued quite convincingly that legal language, i.e.,the language of the law, and in particular its concepts, has to be vague or (semantically) "open" (Kirchhof 1987) ${ }^{4}$ allowing for borderline cases, because no legislative body can foresee future developments in society. The formulation chosen - for example sittenwidrig ('contra bonos mores'/'unethical'/'immoral') must therefore allow for a subsequent dynamic interpretation and application in accordance with societal and political changes. Endicott rightly argues that vagueness is a central technique of normative texts that is needed in order to pursue the purposes of such texts (Endicott 2005: 28). The ensuing flexibility has long been recognised, for instance by Christie (1964: 911).

As mentioned in section 1 and elaborated further in section 3 below, when terms are vague, there is no common ground of understanding at first sight and the problem can only be solved by interpretation.

The precedent argumentation is commonly accepted although the terminology used for describing the phenomenon of vagueness might differ. Mazzarese, for example, points to the fact that the terms 'fuzziness'/'vagueness'/'indeterminacy'/ 'open-texture' are used interchangeably in the literature (Mazzarese 2000: 181, footnote 32 ). The issue is also discussed in this paper and examples are given in section 4 .

\subsubsection{Seemingly coincidence with language for general purpose (LGP)}

Another issue is whether it is appropriate to characterise legal language as a particular LSP. There are arguments for and against this claim. One argument against is that legal language follows the same morphological and syntactic rules as ordinary language, although the distribution/frequency of syntactic patterns is different. Some of them are listed here: well documented is the frequent use of passive voice and deagentivisation. Another feature often shown too is the more frequent use of nominalisations (at least in German in contrast to the Norwegian tendency to use verbal constructions, for example Ruhen des Verfahrens vs. stille saken i bero ('suspension of proceedings'). The special use of mandatory 'shall' and infinitive in English (Williams 2006) ) $^{5}$ or the more frequent use of sein + zu-Infinitiv in German (Matzke 1988) are also often referred to in this context etc. Another argument against is the assumed commonalities with respect to the lexis in LSP and LGP, but where the assumed commonalities disappear as soon as the phenomenon is investigated more closely. By way of illustration reference is made to Luttermann (1999), who analysed how lebenslang ('life sentence') is understood by lawyers and by students 
of humaniora. Another example would be the difference made in German legislation between Leihe ('gratuitous loan') and Darlehen ('loan'). The former presupposes that the borrower is allowed to use the item at no charge (Section 598 German Civil Code $\left.(\underline{B G B})^{6}\right)$. In contrast, the latter presupposes that the borrower must pay for the loan and must return items of the same kind, quality and amount at the end of the loan period (Section $607 \mathrm{BGB}$ ). However, in ordinary German language one frequently uses Leihe even when the loaned item is replaced by a new identical item.

The translator must be aware of these differences in usage.

\subsubsection{High degree of abstraction}

The high degree of abstraction is often referred to and acknowledged as a particular feature of legal language, in particular with respect to German legal language in contrast to the usage in common law legal systems. I agree with Arntz (2001: 2006) who rightly argues that legal relations are inherently abstract and the high degree of abstraction may at least make it difficult to distinguish the conceptual and the terminological levels.

In contrast, Tremblay (2006: 124) seems to advocate only the positive side of using abstract language claiming that

[1]e législateur peut, grâce à l'approche abstraite, viser avec simplicité et concision des situations sociales d'une infinie variété sans encombrer le discours de détails inutiles qui, en contexte législatif, ne jouent en fait qu'un rôle illustratif. (our emphasis)

The abstraction disappears first when the particular legal provision is applied to a concrete case and the judge has to argue why a particular action is covered by the term in question, in other words taking into account the context.

\subsubsection{Polysemy and synonymy}

It is generally acknowledged that polysemy in legal language is the rule rather than the exception: By way of illustration, in German legal language (in a broad sense) the pivotal term Recht refers to two different concepts: (1) //Rechtsordnung// (/legal order/, /the law/) and (2) //subjektives Recht// (/right/).

With respect to synonymy, here German and Latin forms, this kind of synonymy is due to historical reasons (influence of the Roman law on the development of the German legal system). A well-known example being Schuldner/Debitor ('debtor') and Gläubiger/Kreditor ('creditor') where the original Latin forms are now adapted to German orthography (capital letter and ' $k$ ' instead of ' $c$ '); Debitor and Kreditor are often used in ordinary language as well. Other examples would be cession/ Zession/(Forderungs)Abtretung; ex officio/von Amts wegen; ex nunc/von jetzt ab; $\underline{\text { ex }}$ tunc/rückwirkend etc. In Norwegian one can also find parallel designations for these examples: kreditor/fordringshaver; cesjon/overdragelse av fordring adapted to Norwegian spelling, whereas debitor, ex offixio, ex nunc and ex tunc are left unchanged.

\subsubsection{Prescriptivity, plurality of addressees and transdisciplinarity}

Prescriptivity is another obvious specific feature of legal language which is due to the fact that it lays down (legal) rules for a particular issue in a society at a given point of time. This is well reflected in the language use about obligations/duties and rights. 
At the same time these rules are intended for a plurality of addressees, including not only lay persons, but also lawyers and judges in that society and, in case of translation, in the target society as well. ${ }^{8}$ Law, with its core concepts, affects all areas of society and is therefore by necessity inter- and transdisciplinary.

\subsubsection{Terminology}

Every LSP-text is obviously characterised by its domain-related terminology. However, legislative texts, one special genre of legal texts, contain not only legal terminology in the strict sense, but also terminology about all kinds of societal domains that these texts are intended to regulate. Some examples would be in property law: Dienstbarkeit/servitutt ('easement'), Ersitzung/hevd ('prescription') and in family law elterliche Sorge/foreldreansvar ('parental responsibilities') etc.

\subsubsection{Working definition of 'legal language'}

By way of a preliminary conclusion to this section, for the purpose of this paper I propose the following working definition of 'legal language':

legal language $=$ language $u s e$ in different text genres in and about a particular legal system

For reasons of ease, I focus on the analysis of legislative texts. The particular legal system to which I refer here is the legal system of the Federal Republic of Germany. In doing so, an attempt is made to bridge this section to section 4 about legal translation. Before doing so, however, the (inter)connection between legal language (language of the law) and legal interpretation needs to be discussed. This is done in the next section.

\section{Legal Interpretation}

In this section, the focus is on the legal methodology with respect to interpretation in an intra- and interlingual setting. However, let me start with some commonly accepted insights into the relationship between law and language, i.e., that language is inextricably linked to law which in turn is expressed in linguistic terms. (Natural) language is often vague and by nature an imprecise, imperfect and ambiguous instrument $^{9}$ (Tremblay 2006: 113) and the following questions emerge: How can legal language be an appropriate instrument for conveying what the legislator and the judge want to convey? Is legal language really easily accessible and when not, how does interpretation come into play? What is meant by 'interpretation' ${ }^{10}$ in this context? These questions are closely intertwined and a separate answer to each of them is highly problematic.

First "What is meant by 'interpretation'?” Following Larenz (1983: 195) cited in Šarčević (1997: 92), 'interpretation’ (Auslegung) differs from 'understanding.' The latter is seen as an act of automatic cognition without reflection, whereas 'interpretation' begins as soon as the receiver "is forced to reflect about the meaning as a result of an ambiguity or other textual unclarity" (our emphasis).

For illustrative purposes, let me provide the following example: Luttermann (2001) investigated how lay persons interpret Section 240 of the German Criminal Code (StGB) (Nötigungsparagraph). In her explorative study she found that the 
notions of force and threat as well as what would count as inappropriate use of force or threat of serious harm were differently interpreted by the 25 participants of the study who were lay persons in the field of law. She was able to demonstrate that the participants were inclined to understand force (Gewalt) primarily as physical force, as commonly understood in LGP, and not as mental force (vergeistigter Gewaltbegriff) in line with the more recent interpretation of the German Federal Court of Justice $(\underline{\mathrm{BGH}})$. However, the Federal Constitutional Court of Germany (BVerfG) has since constrained this interpretation because such an interpretation would be a violation of Section 103, Subsection 2 German Basic law (Grundgesetz) (predictability of criminal liability; Vorhersehbarkeit für Strafbarkeit) (BVerfG 92,17 cited in Luttermann 2001: 162).

With respect to (legal) interpretation, more precisely interpretation of legislative texts, which the judge has to perform, this is "predominantly a quest for the contextual meaning in order to discover what consequences the text has in the legal situation in which the interpretation is carried out" (Engberg 2002: 375, our emphasis). The judge must justify his outcome of interpretation in the decision (Christensen and Sokolowski 2002: 74) and he is therefore no longer seen as bouche de la loi (Montesquieu), based on the assumption that words have a relatively stable and preestablished meaning which he can easily refer to. Busse (2002: 142) convincingly argues by claiming that legal interpretation (Gesetzesauslegung) has little in common with the activity of 'interpretation' (Interpretieren) in the philological sense because the implications to be drawn represent concrete actions of decisions (konkrete Entscheidungshandlungen) (Busse 2002: 142). ${ }^{11}$ This seems logical as the judge must bring the case to an end by his verdict, either by finding someone guilty or not guilty with the ensuing consequences.

Consider the following example from German adjudication/jurisdiction and the courts' justifications for their decision:

Two parties had signed a contract regarding the construction of an industrial building on one of their neighbouring properties where the wall facing the property of the other owner should be constructed without windows (Fenster). In the appeal procedure (Revisionsverfahren) the $\underline{\mathrm{BGH}}$ had to decide whether this contract was violated because the defendant nevertheless made openings in the wall and filled them with glass bricks (Glasbausteine) where these openings with glass bricks might be classified as windows. The lower court, Oberlandesgericht, had on appeal denied that the defendant's behaviour could be regarded as violation of the contract, arguing that openings with glass bricks could not be regarded as 'windows' in the sense of the contract's wording. In contrast, the $\mathrm{BGH}$, the highest court for such cases, argued that according to the meaning of window (Fenster) in ordinary language its permeability of light (Lichtdurchlässigkeit) is decisive. The court referred to Sections 133, 157 BGB. The openings filled with glass bricks were interpreted by this court as equivalent to windows. In the light of the wording in the contract on no windows (keine Fenster) the BGH decided therefore in favour of the claimant. ${ }^{12}$

Then: Is legal language really easily accessible and when not, how does interpretation come into play?

Although both legislator and judge work with and use legal language as their most important working tool, their approach is quite different. The legislator writes the rules which after enactment are expected to be followed by everyone. In the 
process of formulating rules the legislator uses both LGP and LSP and must search for the best possible (linguistic) precision in order to obtain legal certainty, i.e., a predictable legal framework. In the German legal order the statutory command of predictability (Bestimmtheitsgebot) is regulated by Section 19, Subsection 1 and Section 103, Subsection 2 Basic Law for the Federal Republic of Germany (Grundgesetz für die Bundesrepublik Deutschland), and by Section $1 \underline{\mathrm{StGB}}$, also known as "nullum crimen, nulla poena sine lege certa." However, the rule has to be formulated in such a way that it is also applicable to unforeseen societal (and political) changes. Therefore, the language of the law, as already mentioned, is often "open," "imprecise" and/or "ambiguous" and thus runs counter to Grice's maxims "Avoid obscurity of expression" and "Avoid ambiguity" (Grice 1979: 250). These maxims were originally applied to "ordinary" speech only. In order to be applicable to legislative speech as well, the latter being different in important ways from ordinary conversation, the maxims may require some reformulation (Sinclair 1985: 401). Admittedly Sinclair's examples are from American law (especially pages 401-408), but his theoretical deliberations can still be applied to other legal systems as well, for instance the German one, as long as the competences of the legislative bodies are comparable.

Taking into account the assumption and now commonly accepted view on the pragmatic aspect of language, context occupies the prevalent role in understanding the content (the words used) of an act of communication - applicable also in legal settings. The content (the words used) includes as well the implied content, to use Marmor's (2007: 179) formulation. The implied content covers what in the literature is known as conversational implicatures, conventional implicatures and presuppositions.

When the judge reads and interprets legal rules, he has to find which rules are applicable to the case at hand. His interpretation follows on the basis of some general principles applied in most legal orders. The typical interpretation methods applied both in the Norwegian and German legal orders are grammatical (focus on the wording of the text), historical (focus on how the text came into being, in other words investigation of the preparatory documents in the legislative process, often referred to as travaux préparatoires), systematic (focus on the logical relations between the provision at hand and other provisions in the particular legal order) as originally described by Friedrich Carl von Savigny (19 ${ }^{\text {th }}$ century; Hartung 1999: 64) and since completed by the teleological method where the focus is on the different kinds of purposes (greek telos). Within European Union law, which ranges above the German and also above the Norwegian legal order ${ }^{13}$, in particular the method of dynamic and teleological interpretation is applied. ${ }^{14}$ The judge's argumentation is of vital importance to his decision which should be conveyed in a comprehensible/intelligible way. Nonetheless, in many cases the addressee of the judgment might be in need of a lawyer to explain the wording in more ordinary language.

In German legal order the grammatical method enjoys some supremacy as documented by the following decision of the $\underline{B G H}$ :

Maßgebend für die Auslegung einer Gesetzesvorschrift ist der in dieser zum Ausdruck kommende objektivierte Wille des Gesetzgebers, so wie er sich aus dem Wortlaut einer Gesetzesbestimmung und dem Sinnzusammenhang ergibt, in den diese hineingestellt ist [...]. Dabei ist in aller Regel [...] mit der Auslegung nach dem Wortlaut zu beginnen [...] und zwar schon deshalb, weil das nach dem Wortlaut sprachlich Mögliche, also 
der mögliche Wortsinn, den Bereich bildet und die Grenzen absteckt, innerhalb deren ein vom Gesetz verwendeter Begriff überhaupt ausgelegt werden kann. (BGHZE 46: 76 , our emphasis)

However, current insights in legal methodology also point to other means, such as legal doctrine (herrschende Meinung) as well as "common practical (ethical) arguments" (Dreier 1985: 182).

In addition comes the fact that in contrast to common law, German law, being part of the civil law system, does not usually recognise the practice of precedents (stare decisis). In practice however, German judges (of lower courts) do consider previous decisions, especially from the $\underline{\mathrm{BGH}}$, in order to be consistent with previous decisions. With some rare exceptions case law is nonetheless not considered a formal source of law in the German legal system.

In the next section, the focus is on legal translation drawing on the discussion above on what constitutes legal language and how legal interpretation is applied (or should be applied). I agree with the view held by Šarčević (1997: 92) that it is definitely not the task of the translator to resolve an ambiguity of the source text because this would be an act of interpretation exclusively reserved for the judge.

\section{Legal translation}

Following Engberg (2002: 375), legal translation is a particular communicative activity in the legal field. This activity is done for legal purposes and in legal settings. I refer to the discussion on the pragmatic aspects about the use of legal language (section 2). Usually communication involves at least two parties, each of them either as sender or receiver. In contrast, translating includes the translator as the person in the middle or "information broker" (Obenaus 1995: 250) who is both receiver and sender because the translator receives first the source text that has to be understood and/or interpreted, the difference being as explicated above. But at the same time the translator is the sender when (s)he sends his/her translation to the intended end receiver. The translator has to be ranged on the continuum from expert to non-expert as well. Obviously one cannot expect a translator to have the same level of legal knowledge if (s)he is not a lawyer. But at the same time, I claim, that it is not possible to translate "for legal purposes and in legal settings" (Engberg 2002: 375) without a minimum of insight into the legal systems involved. How to delineate the minimum of insight is ultimately a practical question.

In this section some examples are discussed by way of illustration either as interlingual or intralingual translation (Jakobson 1959).

In section 2 of this paper, particular different features of legal language were listed on which there seems to be consensus, such as vagueness, prescriptivity and plurality of addressees. These features are now discussed based on two genres where the need for legal translation - due to the trends in globalisation - can easily be expected, i.e., legislation and adjudication. Here 'legislation' or 'legislative text' is also understood in the sense of a single provision because it is less probable that a whole law/statute is translated for a client. In scholarly settings this might be different, examples being the Norwegian 2005 Dispute Act (tvisteloven) in English and German translation (Bessing, Schrader and Lipp 2011: 135-447) or the English translation of German acts (Gesetze im Internet ${ }^{15}$. As the judge has to justify his decision 
by referring to the applicable provision(s) the translator is consequently indirectly confronted with the genre of legislation as well. ${ }^{16}$

\section{Example (1) - plurality of addressees}

Context: winding-up proceedings of enterprise in Norway

Cited from the decision of the Norwegian court, Section 66 Norwegian Bankruptcy Act (kkl.) (Act 1984/58):

\section{Begjæring om åpning av konkurs må fremsettes skriftlig for tingretten og angi de omstendigheter begjæringen grunnes på. (kkl. \66)}

*Antrag auf Eröffnung von Konkurs muss vorbringen [Passiv] schriftlich für tingretten und angeben die Umstände der Antrag gegründet wird auf (kkl. \$66) [author’s gloss]

${ }^{*}$ Petition about opening of bankruptcy must file [passive voice] written at tingretten and list the circumstances the petition base [passive voice] upon [author's gloss]

The decision has to be translated for the German parent company so that the company may be able to draw the necessary legal consequences.

My translation of that provision for the German parent company would be:

Ein Antrag auf Konkurseröffnung ist schriftlich beim Gericht [tingretten] einzureichen und hat die den Antrag begründenden Umstände anzugeben ( $\$ 66$ norwegische Konkursordnung [konkursloven])

A petition for opening bankcruptcy has to be filed with the court [tingretten] and has to specify the circumstances on which the petition is based (section 66 Norwegian Bankruptcy Act [konkursloven]) [author's translation]

My suggested translation is based on the assumption that the recipients of the translation, in other words the decision makers in the German parent company and at least their lawyers, have insight into the German Bankruptcy Act (opening, causes, etc.; see Grice's maxim of quantity and relevance, Grice 1979: 249).

I now argue for particular strategies chosen in my suggested translation.

Linguistic issues:

- The literal rendering of åpning av konkurs ('opening of bankruptcy') is kept, albeit as a compound for the reason that compounds are more frequently used than gerund and in particular because Konkurseröffnung was used in the former German Bankruptcy Act (in force until 1994).

- According to German genre conventions the syntactical construction sein + zu Inf. is used - instead of the modal verb müssen and passive voice of the main verb covering the inherent prescriptivity of a legal norm.

- According to German genre conventions the Norwegian relative clause without the usual relative pronoun som ('which' or 'that') de omstendigheter begjæringen grunnes på ('the circumstances on which the petition is based') is rendered as an adjectival participle as premodifier of the head Umstände, i.e. die [...] begründenden Umstände.

- According to German genre conventions the source of the pertinent act is cited after the Section.

\section{Content based issues:}

Instead of rendering tingretten ('the district court') by [das] Amtsgericht which would be the functional equivalent, I opted for the neutral term [dem] Gericht ('the 
court'), the superordinate term for different kinds of courts. To use the superordinate term in such cases would be in line with a strategy advocated, for example, by Šarčević (1990: 158). The information about which court in the source culture has the jurisdiction (regulated by Norwegian Bankruptcy Act) is in my opinion, and again with reference to the maxim of quantity, not the task of the translator. It is not the task of the translator to provide full information about the procedural law of the legal order in the source culture.

\section{Example (2) Mensch ('human being') - vagueness}

In contrast to the first example which was discussed from the viewpoint of an interlingual translation, this example is discussed from the viewpoint of an intralingual translation (Jakobson 1959) and deals with a vague legal concept rendered by the same linguistic expression.

In legislation the concept of //Mensch// is referred to in Section $212 \underline{\mathrm{StGB}}$ and in Section 1 BGB.

The question is here: Who is considered a //Mensch// ('human being')? The Duden Rechtschreibung gives as explication:

“[ein] mit der Fähigkeit zu logischem Denken und zur Sprache, zur sittlichen Entscheidung und Erkenntnis von Gut und Böse ausgestattetes höchstentwickeltes Lebewesen." ('maximal developed creature,' our emphasis). ${ }^{17}$

At what point does this creature's life begin? The legislator has established two different limits for the beginning. In Sections 211 to 222 the StGB regulates different offences against life (!), until the onset of labour, a human being (Mensch) is seen (only) as a foetus/embryo, and the termination of pregnancy (Section $218 \underline{\mathrm{StGB}}$ ) is therefore treated as abortion with no penal sanctions. However, after the onset of labour - "beginning of childbirth" (Schönke and Schröder 1988: 1384) - a Mensch exists, and killing is then seen as homicide in the sense of Section 212 StGB. ${ }^{18}$

This definition of the concept //Mensch// applies only in the case of StGB. In contrast, in the BGB the legislator also uses the concept //Mensch//, (1) where a human being in the eyes of the law is a natural person, having legal capacity, and whose legal capacity begins on completion (!) of birth (Section $1 \underline{\mathrm{BGB}}$ ). (2) In addition, the $\mathrm{BGB}$ contains a provision about a point other than the completion of birth at which human life begins, i.e., conception (!). Anyone who at the time of the devolution of an inheritance did not yet live, but was already conceived, is considered born before the devolution of the inheritance (Section 1923, subsection 2 BGB).

This example shows once again how legal interpretation may unveil the vagueness of a given concept depending on a particular area or branch of law and clarify its polysemy when the legislator uses seemingly the same term but nonetheless with different content ('meaning'). The translator has to keep this in mind and should be aware of the translation strategies to overcome this challenge. With respect to the example at hand, Section 233 Norwegian Civil Penal Code (straffeloven) uses en andens ('another person's) instead of the possible expression menneske. 


\section{Example 3 - terminology in legal translation}

The following example stems from a totally different setting, that is excerpts from a Norwegian court decision which had to be translated by candidates at the National Translation Accreditation Exam (translatøreksamen). This example challenged among other things the candidate's (legal) knowledge with respect to a particular term to be used. The candidates are not allowed to have internet access but may otherwise use every possible translation means such as dictionaries, encyclopedias, background information and/or glossaries downloaded on their laptop.

The extract of the case at hand deals with a private lawsuit where the claimant demanded a declaratory judgement. At the lower court, the decision was in favour of the defendant and the claimant filed an appeal against this decision. In contrast, at the court of appeal, the decision was in favour of the claimant. The decision stated that the defendant had to pay compensation to the claimant:

Dagens Næringsliv AS betaler til Jan Kokkin 60.000 - sekstitusen - kroner innen 2 - to uker etter forkynnelsen av denne dom med tillegg av forsinkelsesrente etter forsinkelsesrenteloven $₫ 3$ første ledd første punktum fra forfall og til betaling skjer. (our emphasis)

Dagens Næringsliv AS shall pay Jan Kokkin NOK 60,000 - sixty thousand - within 2 - two - weeks after the service of this judgment, in addition to interest on overdue payments pursuant to Section 3, subsection one, first clause of the Norwegian Act relating to interest on overdue payments [forsinkelsesrenteloven], from the due date and until payment is made [author's translation]

What might cause problems in the translation process is, in my view, the translation of forkynnelse.

The one candidate for the language pair Norwegian-German ${ }^{19}$ at that exam opted for Zustellung. To provide more data, I also looked at the translations into English where 3 out of 9 candidates opted for 'service' and the rest for 'pronouncement.' However, in what follows, I concentrate on the translation challenge into German only.

Looking for parallel texts, a subsequent investigation was made into the translation of the pertinent provision in the Norwegian 2005 Dispute Act (Bessing, Schrader and Lipp 2011). Here the translation into German "was kept closely to the original wording of the Norwegian text" (Bessing, Schrader and Lipp 2011:135) and shows in Section 19-5 verkündet ('forkynnes') whereas, in the same context, the unofficial translation into English by the Norwegian Ministry of Justice shows 'served.'

The translator who has retrieved parallel texts has to decide if Verkündung/ verkünden might be a false friend and should be replaced by Zustellung/zustellen in the context of the Kokkin case. In order to decide this, the translator should analyze two additional texts more closely: the rulings of the Norwegian Act relating to the Courts of Justice (domstolloven) and the German Code of Civil Procedure (Zivilprozessordnung, ZPO).

Section 315 ZPO in combination with Section 310 uses verkündet and refers to the hearing in which the judgment is pronounced. In addition, judgments are also zugestellt ('served'; $\$ 317$ ZPO) and the parties are usually not present at the hearing (in a civil court procedure!). ${ }^{20}$ My conclusion is therefore that in the given context (exam situation), both Verkündung and Zustellung respectively might be adequate 
translations of the Norwegian term forkynnelse. If one takes into consideration the legally possible absence of the parties, however, Zustellung is the only way in which the parties are informed about the outcome of the proceedings. But such in-depth investigations are not feasible in an exam situation.

To return to the candidate's translation Zustellung in the exam situation: This

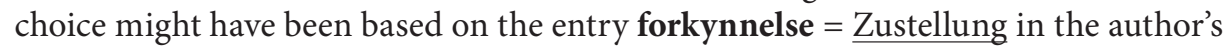
Norwegian-German legal dictionary and has therefore not challenged the candidate any further.

\section{Concluding remarks}

The aim of this article was to enhance the insight into the complex relationship between legal language, legal interpretation and legal translation which recurrently challenges the participants of a particular domain-specific communicative situation. This situation is explained as a complex communicative-cognitive procedure that takes a pragmatic approach into consideration to reach its addressees on a continuum from lay persons to experts.

The analysis of the few "typical" examples in the case study (section 4) reveals that, as expected, different kinds of knowledge are indispensable in order to achieve a felicitous communicative act. The analysis shows that a high degree of knowledge of the particular legal system and its subdomains is of paramount importance to a successful result both in intra- and interlingual translation. This knowledge should be easily retrievable: It may already be stored in the translator's "black box" or has to be searched for in different kinds of documents dealing with this particular piece of knowledge from which the necessary inferences and implications can be drawn.

As the basis for the whole task the translator must be able to understand/interpret the particular legal language and must be aware of not taking the words at their "face value" in order to render their meaning in the target language.

\section{NOTES}

1. This paper is an extended version of my talk given at the $19^{\text {th }}$ European Symposium on LSP Languages for Special Purposes, Vienna, 8-10 July 2013.

2. In contrast to Angermeyer (2011), for example, who investigates only the spoken interaction in legal settings drawing on several earlier studies.

3. See, for example, Lind $(1994 ; 2004)$ drawing on the language combination Norwegian-English; Roald and Whittaker $(2010 ; 2012)$ on the language combination Norwegian-French and Simonnæs (1994a; 1994b; 2002; 2008) on the language combination Norwegian-German.

4. See also Busse's analysis of the section on theft in the German Criminal Code where he argues, quite rightly so, that German law texts are usually characterised by a high degree of semantic abstraction with a subsequently great semantic openness (Offenheit) or what lawyers would call 'need for interpretation' (Interpretationsbedürftigkeit) (Busse 2002: 150).

5. In the plain English movement, however, this use has been criticised and their proponents argue for its replacement by 'must.'

6. Gesetze im Internet. German Civil Code/Bürgerliches Gesetzbuch. http://www.gesetze-iminternet.de/englisch_bgb. In the rest of this paper, after their first mention, German acts and German legal institutions are referred to by their German designations unless otherwise deemed necessary.

7. Although this paper has German legal language as its primary research object, in the context of synonymy it is worth noting that English legal language has a tendency to accumulate different more or less synonymous terms, for instance in the context of a last will or testament as in the following example: I N.N.1, being of sound mind and body, do hereby give, devise, and bequeath 
all my possessions to N.N.2. 'devise' and 'bequeath' are more or less synonyms of 'give' [something by will to another] even if the first two verbs were originally used in different contexts, for instance 'devise' in the context of giving real property in contrast to 'bequeath' in the context of giving personal property by will to another. The three different verbs are used to clarify that all the property, real, personal, and monetary is to be inherited.

8. See also the discussion in Simonnæs (2005/2012).

9. Original wording: "Le langage naturel [...] constitue un instrument imprécis, imparfait et ambigu."

10. See also Simonnæs (2009) with a more in-depth analysis on the phenomenon of understanding and interpretation.

11. See Busse (2002:142) "Die 'Konkretisierung des Gesetzestextes' besteht häufig weniger in einer expliziten semantischen Argumentation, als in der Vornahme faktischer Rechtsentscheidungen (und Subsumtionen), für die der Gesetzestext dann eher argumentativ, begründend herangezogen wird" (our emphasis).

12. For detailed argumentation see Lindenmaier-Möhring $\$ \$ 133,157$ BGB Nr. 17.

13. Although Norway is not a member of the EU, it is strongly affected by EU legislation due to its membership in the European Economic Area.

14. For more details see Franklin (2013: 220) who cites the following decision of the European Court of Justice: "[...] every provision of Community law must be placed in its context and interpreted in the light of the provisions of Community law as a whole, regard being had to the objectives thereof and to its state of evolution at the date on which the provision in question is to be applied" (our emphasis).

On the methods of interpretation applied to EU-law see also Itzcovich (2009), Derlén (2009: especially 326-332 and 2014: 21), Martinico and Pollicino (2012: 129-130) and Lenaerts and GutiérrezFons (2013), to name but a few. However, to discuss the methodological approaches of interpretation of EU law in depth falls beyond the scope of this paper.

15. English translations of many Norwegian laws can be found on the Internet. See for example the unofficial English translation of Norwegian laws: Translated Norwegian Legislation, University of Oslo, <http://app.uio.no/ub/ujur/oversatte-lover/english.shtml>.

16. See for instance Der Bundesgerichtshof, <http://juris.bundesgerichtshof.de/cgi-bin/rechtsprechung/document.py?Gericht=bgh\&Art=en\&sid=f4ab7f12ae2473357f3855acf97b05d6\&Sort=3\&nr $=62856 \&$ pos $=2 \&$ anz $=41>$., where reference is made to Sections 1603,1360 and $1360 \mathrm{a}$ BGB together with the Leitsatzentscheidung (kind of guiding principle which might be applied to similar subsequent cases). Kötz (1973: 259-260) pointed out: “['die [...] sogenannten Leitsätze'] werden [...] gelegentlich von den Gerichten [...] wie ein Gesetzesparagraph [angewendet]" (author's emphasis).

17. See the somewhat different explication in the Oxford Dictionary: "a man, woman, or child of the species Homo sapiens, distinguished from other animals by superior mental development, power of articulate speech, and upright stance" (our emphasis).

18. Note, however, until 1998, the StGB had a separate provision when the mother killed her newborn baby during or within 24 hours of the birth (Section 217 StGB, Kindstötung; neonaticide). Dölling (2009) refers to the prevalent view that neonaticide and infant homicide now are subsumed under Sections $211-213 \underline{\text { StGB }}$ depending on the particular circumstances in each case by drawing on many court decisions of the BGH and some of the BVerG.

19. The number of candidates for the language pair Norwegian-German in this case is unusually low; in contrast the number of candidates for the language pair Norwegian-English is always much higher. This is the reason why their translations are mentioned as well with respect to this particular entity.

20. Personal communication from German lawyer Rechtsanwalt Florian Paintner of $7^{\text {th }}$ March 2014.

\section{REFERENCES}

Angermeyer, Philipp Sebastian (2011): Language and the Law. In: Jef Verschueren and JanOla Östman, eds. Handbook of Pragmatics, Amsterdam: John Benjamins, 211-230.

Arntz, Reiner (2001): Fachbezogene Mehrsprachigkeit in Recht und Technik. Hildesheim: Olms. Baumann, Klaus-Dieter (2004): Die Entwicklungsperspektiven der Fachsprachenforschung zu Beginn des neuen Jahrhunderts. In: Lew N. Zyватоw, ed. Translation in der globalen Welt und neue Wege in der Sprach- und Übersetzerausbildung. Innsbrucker Ringvorlesungen zur Translationswissenschaft, II. Frankfurt /M.: Peter Lang, 133-163. 
Bessing, Johanna, Schrader Johan and Lipp, Volker, trans. (2011): The Norwegian 2005 Dispute Act in Norwegian and in German and English Translation. In: Volker Lipp and Haukeland Halvard Fredriksen, eds. Reforms of Civil Procedure in Germany and Norway. Tübingen: Mohr Siebeck, 135-447.

Bhatia, Vijay, Candlin, Christopher N. and Gotti, Maurizio, eds. (2003): Legal Discourse in Multilingual and Multicultural Contexts. Bern: Lang.

Bhatia, Vijay, Engberg, Jan, Gotti, Maurizio and Heller, Dorothee, eds. (2005): Vagueness in Normative Texts. Bern: Lang.

Bix, Brian H. (2012): Legal Interpretation and the Philosophy of Language. In: Peter M. Tiersma and Lawrence M. SolAn, eds. The Oxford Handbook of Language and Law. Oxford: Oxford University Press, 145-155.

BowERs, Frederick (1989): Linguistic Aspects of Legislative Expression. Vancouver: University of British Columbia Press.

Busse, Dietrich (1999): Die juristische Fachsprache als Institutionensprache am Beispiel von Gesetzen und ihrer Auslegung. In: Lothar Hoffmann, Hartwig Kalverkämper and Herbert Ernst WiEgAnd, eds. Fachsprachen - Languages for Special Purposes. Ein internationales Handbuch zur Fachsprachenforschung und Terminologiewissenschaft - An International Handbook of Special Languages and Terminology Research. Vol. 2. Berlin/New York: de Gruyter, 1382-1391.

Busse, Dietrich (2002): Bedeutungsfeststellung, Interpretation, Arbeit mit Texten? Juristische Auslegungstätigkeit in linguistischer Sicht. In: Ulrike Hass-Zumkenr, ed. Sprache und Recht. Berlin: de Gruyter, 136-162.

Christensen, Ralph and Sokolowski, Michael (2002): Wie normativ ist Sprache? Der Richter zwischen Sprechautomat und Sprachgesetzgeber. In: Ulrike Hass-ZumkenR, ed. Sprache und Recht. Berlin: de Gruyter, 64-79.

Christie, George C. (1964): Vagueness and Legal Language. Minnesota Law Review. 48:885-911.

Clauss, Karl (1974): Scheinpräzision in der Rechtssprache. Muttersprache, Zeitschrift zur Pflege und Erforschung der deutschen Sprache. 1:21-38.

Derlén, Mattias (2009): Multilingual Interpretation of European Union Law. Alphen aan den Rijn: Kluwer Law International.

DerléN, Mattias (2014): Multilingualism and legal integration in Europe. In: Rita Temmerman and Marc Van Campenhoudt, eds. Dynamics and Terminology: An Interdisciplinary Perspective on Monolingual and Multilingual Culture-bound Communication. Amsterdam: John Benjamins, 17-41.

Dölling, Dieter (2009): Die Kindestötung unter strafrechtlichen Aspekten. Forensische Psychiatrie, Psychologie, Krimonologie. 3(1):33-36.

Dreier, Ralf (1985): Interpretation. In: Görres-Gesellschaft, ed. Staatslexikon: Recht, Wirtschaft, Gesellschaft. Freiburg: Herder, 179-183.

Endicott, Timothy A. O. (2000): Vagueness in Law. Oxford: Oxford University Press.

Endicotт, Timothy A. O. (2001): Law is necessarily vague. Legal Theory. 7(4): 379-385.

Endicotт, Timothy A. O. (2005): The Value of Vagueness. In: Vijay Bhatia, Jan Engberg, Maurizio Gotti and Dorothee Heller, eds. Vagueness in Normative Texts. Bern: Lang, $27-48$.

ENGBERG, Jan (2002): Legal meaning assumptions - What are the consequences for legal interpretation and legal translation? International Journal for the Semiotics of Law. 15:375-388.

Engberg, Jan (2012): Word Meaning and the Problem of a Globalized Legal Order. In: Peter M. Tiersma and Lawrence M. Solan, eds. The Oxford Handbook of Language and Law. Oxford: Oxford University Press, 175-186.

Franklin, Christian (2013): Reelle hensyn i EU-retten. In: Sverre Blandhold. De beste grunner. Reelle hensyn i juridisk argumentasjon. Oslo: Gyldendal, 198-227.

Gilbertson, Gerard (1988): Ambiguity and Vagueness in International Law: Some German and English Examples (Part II). Lebende Sprachen. 4:162-166. 
GodDard, Christopher (2010): Legal Linguistics: As (In)substantial as Ghosts and True Love? In: Davide Simone Giannoni and Celina Frade, eds. Researching Language and the Law. Textual Features and Translation Issues. Bern: Lang, 199-211.

Gotтi, Maurizio and Williams, Christopher, eds. (2010): Legal Discourse across Languages and Cultures. Bern: Lang.

Grice, Paul H. (1979): Logik und Konversation. In: Georg Meggle, ed. Handlung, Kommunikation, Bedeutung. Frankfurt/M.: Suhrkamp, 243-265.

Hartung, Marion (1999): Friedrich Carl von Savignys juristische Methodenlehre in der Ausarbeitung seines Schülers Jacob Grimm. In: Kristin BüHRIg and Yaron Matras, eds. Sprachtheorie und sprachliches Handeln. Festschrift für Jochen Rehbein zum 60. Geburtstag. Tübingen: Stauffenberg, 61-80.

Hattenhauer, Hans (1987): Zur Geschichte der deutschen Rechts- und Gesetzessprache. Göttingen: Vandenhoeck und Ruprecht.

Heutger, Viola (2006): Der Platz der juristischen Fachsprache in der Experten-Laien-Kommunikation. Hermes. Journal of Language and Communication Studies. 36:55-63.

Hofmmann, Lothar (1984): Seven Roads to LSP. Special Language/Fachsprache. International Journal of LSP. 6(1/2):28-38.

HofFmann, Lothar (1976/1985): Kommunikationsmittel Fachsprache. Eine Einführung. Tübingen: Narr.

Homberger, Dietrich (1990): Von Experte zu Laie. Fachsprachliche Kommunikation und Wissenstransfer. In: Gert Rickheit and Sigurd Wichter, eds. Dialog. Festschrift für Siegfried Grosse. Tübingen: Niemeyer, 477-490.

Itzcovich, Giulio (2009): The Interpretation of Community Law by the European Court of Justice. German Law Journal. 10(05):537-559.

Jakobson, Roman (1959): On Linguistic Aspects of Translation. In: Reuben A. Brower, ed. On Translation. Cambridge: Harvard University Press, 232-239.

Kirch Hof, Paul (1987): Die Bestimmtheit und Offenheit der Rechtssprache. Berlin/New York: de Gruyter.

Kischel, Uwe (2009): Legal Cultures - Legal Languages. In: Frances Olsen, Alexander Lorz and Dieter Stein, eds. Translation Issues in Language and Law. New York: Palgrave Macmillan, 7-17.

КӧтZ, Hein (1973): Über den Stil höchstrichterlicher Entscheidungen. Rabels Zeitschrift für ausländisches und internationales Privatrecht. 37:245-263.

Kurzon, Dennis (1989): Language of the Law and Legal Language. In: Christer Laurén and Marianne Nordman, eds. Special Language. From Humans Thinking to Thinking Machines. Clevedon: Multilingual Matters, 283-290.

Kurzon, Dennis (1997): 'Legal language': varieties, genres, registers, discourses. International Journal of Applied Linguistics. 7(2):119-139.

LANE, Alexander (1975): Tätigkeit und Aufgaben des Internationalen Instituts für Rechts- und Verwaltungssprache. In: Günther HaEnsCH and Alexander LANE, eds. Bibliographie der Wörterbücher und Nachschlagewerke: Rechts- und Verwaltungssprache, Wirtschaft und Politik in 37 Sprachen. Berlin: Internationales Institut für Rechts- und Verwaltungssprache, 4-45.

Larenz, Karl (1983): Methodenlehre der Rechtswissenschaft. Berlin: Springer.

Lenaerts, Koen and Gutiérrez-Fons, José A. (2013): To Say What the Law of the EU Is: Methods of Interpretation and the European Court of Justice. EUI AEL Working Papers 2013/9. European University Institute.

LIND, Åge (1994): On the transposition of legal terms. 'Transparency' vs. 'correctness' in Norwegian-English terminology. Netvoerk LSP-SSP Nyhedsbrev. 9:77-84.

Lind, Åge (2004): Navigating Through the Minefields. On the Making of an English-Norwegian Dictionary of Law. In: Geoffrey Williams and Sandra Vessier, eds. Proceedings of the $11^{\text {th }}$ Euralex international congress. Université de Bretagne-Sud, 595-602. 
Lindenmaier, Fritz and Philipp Möhring (s.a.): Nachschlagewerk des Bundesgerichtshofs (Losebl.-Ausg.). München: Beck.

Luttermann, Karin (1999): Wie lang ist lebenslang? Juristische Definitionssemantik und allgemeiner Sprachgebrauch. Deutsche Sprache. Zeitschrift für Theorie, Praxis, Dokumentation. 3:263-248.

Luttermann, Karin (2001): Gesetzesinterpretation durch Juristen und Laien: Ein rechtslinguistischer Beitrag zum Nötigungstatbestand. Linguistische Berichte. Forschung, Information, Diskussion. 186:157-174.

Marmor, Andrei (2007): What Does the Law Say? Semantics and Pragmatics in Statutory Language. In: Paolo Comanducci and Riccardo Guastini, eds. Analisi e diritto 2007: Ricerche di giurisprudenza analitica. Turin: G. Giappichelli Editore, 127-140.

Martinico, Giuseppe and Pollicino, Oreste (2012): The Interaction Between Europe's Legal Systems. Judicial Dialogue ad the Creation of Supranational Laws. Cheltenham: Edward Elgar Publishing.

Mattila, Heikki E.S. (2013): Comparative Legal Linguistics. Language of Law, Latin and Modern Lingua Francas (translated from the Finnish by Christopher GodDARD). London: Ashgate.

Matzke, Brigitte (1988): Die Modalität der Fügung, sein + zu + Infinitiv in juristischen Texten. Deutsch als Fremdsprache. Zeitschrift zur Theorie und Praxis. 2:72-74.

Mazzarese, Tecla (2000): Legal interpretation as Translation. In: Guiseppe Zaccaria, ed. Übersetzung im Recht - Translation in Law (Ars interpretandi, 5). Münster: LIT, 161-188.

Mellinkoff, David (1963/1990): The Language of the Law. $7^{\text {th }}$ ed. Boston/Toronto: Little, Brown and Company.

Müller-Tochtermann, Helmut (1959): Struktur der deutschen Rechtssprache. Beobachtungen und Gedanken zum Thema Fachsprache und Allgemeinsprache. Muttersprache. Zeitschrift zur Pflege und Erforschung der deutschen Sprache/Gesellschaft für die deutsche Sprache. 69(2-3):84-92.

Obenaus, Gerhard (1995): The Legal Translator as Information Broker. In: Marshall MorRis, ed. Translation and the Law. Amsterdam/Philadelphia: John Benjamins, 247-259.

Ogden, Charles Kay and Richards, Ivor Armstrong (1923/1972): The Meaning of Meaning. $10^{\text {th }}$ ed. London: Routledge.

ОкsaAR, Els (1979): Sprachliche Mittel in der Kommunikation zwischen Fachleuten und Laien im Bereich des Rechtswesens. In: Wolfgang MentruP, ed. Fachsprachen und Gemeinsprache (Jahrbuch 1978 des Instituts für deutsche Sprache). Düsseldorf: Schwann, 100-113.

Picht, Heribert (1996): Fachkommunikation - Fachsprache. In: Gerhard Budin, ed. Multilingualism in specialist communication. Proceedings of the $10^{\text {th }}$ European LSP Symposium, Vienna, 29 Aug. - 1 Sept. 1995. Vol. 1. Vienna: International Network for Terminology, 27-45.

Picht, Heribert (1999): Die Begriffe 'Fachmann' und 'Laie' in der Fachkommunikation. In: Wilfried WiEDEN and Andreas WeIss, eds. Internationale Wirtschaftsbeziehungen: Mehrsprachige Kommunikation von Fachwissen. Göppingen: Kümmerle Verlag, 29-42.

Poscher, Ralf (2012): Ambiguity and Vagueness in Legal Interpretation. In: Peter M. Tiersma and Lawrence M. Solan, eds. The Oxford Handbook of Language and Law. Oxford: Oxford University Press, 128-144.

Roald, Jan and Whittaker, Sunniva (2010): Verbalization in French and Norwegian legislative texts. A contrastive case study. In: Maurizio Gotтi and Christopher Williams, eds. Legal Discourse across Languages and Cultures. Bern: Lang, 95-107.

Roald, Jan and Whittaker, Sunniva (2012): Les normes discursives dans le langage juridique: défis terminologiques et traductologiques. In: Mariette Meunier, Marion ChARReT-DeL Bove and Eliane Damette, eds. La traduction juridique. Points de vue didactiques et linguistiques. Lyon: Université de Lyon, 43-53.

ŠARČEVIĆ, Susan (1990): Strategiebedingtes Übersetzen aus den kleineren Sprachen im Fachbereich Jura. Babel. 36(3):155-166.

ŠARČEviĆ, Susan (1997): New Approach to Legal Translation. The Hague: Kluwer Law International. 
Saussure, Ferdinand de (1916/1967): Grundfragen der Allgemeinen Sprachwissenschaft (translated from the French by Herman Lommel). Berlin: de Gruyter.

Schönke, Adolf and SchröDer, Horst (1988). Strafgesetzbuch. $23^{\text {rd }}$ ed. (Commentary first by Adolf Schönke. Continued by Horst Schröder und Theodor Lenckner). München: Beck.

Simonnæs, Ingrid (1994a): On the problem of equivalence in Norwegian and German legal language. In: Magnar Brekke, Øivin Andersen, Trine Dahl et al. eds. Applications and implications of current LSP research (Proceedings of the 9th European LSP Symposium, Vol. II). Bergen: Fagbokforlaget, 852-860.

Simonnæs, Ingrid (1994b): Norsk-tysk juridisk ordbok [Norwegian-German legal dictionary]. Bergen: Fagbokforlaget.

Simonnæs, Ingrid (2002): Zur Frage der rechtskulturellen Unübersetzbarkeit anhand eines Vergleiches zwischen Norwegen und Deutschland. In: Lars Eriksen and Karin LutTeRMANN, eds. Juristische Fachsprache. Kongressberichte des $12^{\text {th }}$ European Symposium on Language for Special Purposes, Brixen/Bressanone 1999. Münster: LIT Verlag, 133-156.

SimonnÆs, Ingrid (2005): Fachkommunikation im Recht unter Berücksichtigung der Mehrfachadressierung. In: LERCH, Kent (Hrsg.). Recht vermitteln. Strukturen, Formen und Medien der Kommunikation im Recht. Berlin: de Gruyter, 377-397.

Simonnæs, Ingrid (2007): Vague legal concepts. A contradictio in adjecto? In: Bassey Edem Antia, ed. Indeterminacy in Terminology and LSP. Studies in honour of Heribert Picht. Amsterdam/Philadelphia: Benjamins, 119-134. [reprint in Simonnæs 2012]

Simonnæs, Ingrid (2008): Reflektionen [!] über die übersetzungsorientierte Terminologiearbeit bei Rechtstexten mit Beispielen aus dem Sprachenpaar Norwegisch-Deutsch. In: Hans P. KRINGS and Felix MAYER, eds. Sprachenvielfalt im Kontext von Fachkommunikation, Übersetzung und Fremdsprachenunterricht. Für Reiner Arntz zum 65.Geburtstag. Berlin: Frank \& Timme, 381-390. [reprint in Simonnæs 2012]

Simonnæs, Ingrid (2009): Verstehen und Interpretation in der intralingualen Rechtskommunikation. Voraussetzung und Anwendung in Theorie und Praxis. trans-kom 2(2):160-172. [reprint in Simonnæs 2012]

SimonN«S, Ingrid (2012): Rechtskommunikation national und international im Spannungsfeld von Hermeneutik, Kognition und Pragmatik. Berlin: Frank \& Timme.

Sinclair, Michael B.W. (1985): Law and Language: The Role of Pragmatics in Statutory Interpretation. University of Pittsburgh Law Review. 46:373-420.

Tiersma, Peter M. (1999): Legal Language. Chicago/London: The University of Chicago Press.

Tiersma, Peter M. (2012): A History of the Languages of Law. In: Peter M. Tiersma and Lawrence M. Solan, eds. The Oxford Handbook of Language and Law. Oxford: Oxford University Press, 13-26.

Tiersma, Peter M. and Solan, Lawrence M., eds. (2012): The Oxford handbook of language and law. Oxford: Oxford University Press.

Tremblay, Richard (2006): L'abstraction au service de la clarté en rédaction législative. In: Anne WAgner and Sophie Cacciaguidi-Fahy, eds. Legal Language and the Search for Clarity. Bern: Lang, 105-140.

Williams, Christopher (2006): Fuzziness in Legal English: What Shall we Do with Shall? In: Anne Wagner and Sophie Cacciaguidi-Fahy, eds. Legal Language and the Search for Clarity. Bern: Lang, 237-263. 